\title{
MENINGKATKAN KETERAMPILAN BERBICARA MELALUI PENGGUNAAN MEDIA PANGGUNG BONEKA PADA KELOMPOK A1TK MADUKISMO
}

\author{
Oleh: \\ Risky Ramadani \\ PPG SM-3T PG PAUD UNY 2016 \\ moo_bee yahoo.com
}

\begin{abstract}
Abstrak
Penelitian ini bertujuan meningkatkan keterampilan berbicara pada anak-anak di TK Madukismo, Bantul, Yogyakarta melalui penggunaan media panggung boneka. Keterampilan berbicara pada anak-anak dilihat dari kemampuan anak dalam ikut aktif berpartisipasi mengungkapkan ide/gagasan dan menjawab pertanyaan apa, siapa, mengapa dan dimana. Jenis penelitian ini merupakan Penelitian Tindakan Kelas kolaboratif, Subjek yang diteliti anak-anak dari kelompok A1 TK Madukismo yang berjumlah 17 anak, terdiri dari 8 anak laki-laki dan 9 anak perempuan. Teknik pengumpulan data menggunakan observasi dan dokumentasi. Teknik analisis data menggunakan deskriptif kualitatif dan kuantitatif. Hasil penelitian menunjukkan bahwa terjadi peningkatan keterampilan berbicara pada anak, hal ini dibuktikan pada kemampuan awal keterampilan berbicara yaitu 52,8\% termasuk dalam kriteria kurang baik, pada Siklus I meningkat 12,8\% menjadi 65,6\% termasuk dalam kriteria cukup, dan pada Siklus II meningkat $22,5 \%$ menjadi $88,1 \%$ termasuk dalam kriteria baik. Langkah-langkah yang dilaksanakan untuk meningkatkan keterampilan berbicara yaitu guru bercerita, tanya jawab tentang cerita yang dibawakan guru, anak mengulang cerita yang dibawakan guru, guru memberi motivasi kepada anak untuk ikut aktif berpartisipasi dalam kegiatan.
\end{abstract}

Kata Kunci: keterampilan berbicara, panggung boneka, kelompok A1

\begin{abstract}
The research was aimed to improve the speaking skill of students in TK Madukismo, bantul, Yogyakarta using puppet stage media. The students' speaking skill was assessed from their active participation in expressing ideas and answering questions asking what, who, why, why, and where. The study is categorized into collaborative classroom action research. Subjects of the research were 17 students of TK Madukismo in group A1 comprising 8 boys and 9 girls. The media was used in cycle I and II as complementary media aside of hand and finger puppet in the storytelling activity. Data was obtained from observation and documentation and was analyzed both in qualitative and quantitative domain descriptively. The research result showed that there was an increase in the students' speaking skill. This was proven by the initial speaking skill having its level in $52.8 \%$,thus categorized as inadequate, which in cycle I increased $12.8 \%$ as much reaching into $65.6 \%$ categorized as adequate. In cycle II the level increased significantly (22.5\%) into $88.1 \%$ and was categorized as decent. Procedures of the treatment were: 1) teacher told a story, 2) teacher elicited comprehension question upon the story, and 3) teacher motivated students to actively participate in the activity. The use of the puppet stage for storytelling activities can improve the speaking skill.
\end{abstract}

Keywords: speaking skill, puppet stage, group A1 


\section{PENDAHULUAN}

Anak merupakan sosok individu yang memiliki karakteristik atau keunikan tersendiri, anak-anak berada pada masa pertumbuhan dan perkembangan yang perlu dioptimalkan. Karakterisitik dan keunikan yang dimiliki anak usia dini itulah yang membedakan setiap anak dengan usia di atasnya, sehingga pendidikannya pun dipandang perlu dikhususkan (Slamet Suyanto, 2005:1).

Pendidikan Anak Usia Dini berbeda dengan pendidikan yang lainnya, dalam Pendidikan Anak Usia Dini, guru memfasilitasi atau mengembangkan semua aspek perkembangan anak pada masa tersebut segala potensi dan perkembangannya harus dioptimalkan.

Aspek perkembangan yang harus dioptimalkan meliputi aspek perkembangan kognitif, fisik, sosial-emosional, dan bahasa.Salah satu bidang pengembangan dasar yang penting bagi anak adalah perkembangan bahasa.Bahasa merupakan bentuk utama dalam mengekspresikan pikiran dan pengetahuan apabila anak mengadakan hubungan dengan orang lain. Anak yang sedang tumbuh dan berkembang mengkomunikasikan kebutuhan, pikiran, dan perasaannya melalui bahasa dengan kata-kata yang mempunyai makna.

Henry Guntur Tarigan (2008: 1) mengungkapkan bahwa keterampilan berbahasa dalam bahasa Indonesia meliputi empat aspek, yaitu menyimak, berbicara, membaca, dan menulis.

Keempat aspek tersebut disebut juga sebagai catur tunggal keterampilan berbahasa, karena keempat aspek tersebut merupakan satu kesatuan, saling berhubungan, dan tidak bisa dilepaskan, namun berbeda antara satu dengan yang lainnya dan juga berbeda dari segi prosesnya.

Nurbiana Dhieni (2008: 3.9) kemampuan berbahasa yang paling umum dan efektif dilakukan adalah kemampuan berbicara. Hal ini selaras dengan karakteristik umum kemampuan bahasa anak pada usia tersebut. Karakteristik ini meliputi kemampuan anak untuk dapat berbicara dengan baik, melaksanakan tiga perintah lisan secara berurutan dengan benar; mendengarkan dan menceritakan kembali cerita sederhana dengan urutan yang mudah dipahami; menyebutkan nama, jenis kelamin dan umurnya; memiliki lebih banyak kata-kata untuk mengekspresikan ide pada orang lain, menggunakan kata sambung, menggunakan kata tanya, menyusun kalimat, mengucapkan lebih dari tiga kalimat, dan mengenal tulisan sederhana.Pengembangan bahasa yang harus dikuasai oleh peseta didik salah satunya yaitu berbicara.

$$
\text { Vygotsky (dalam Harun }
$$

Rasyid,dkk., 2009:130) menjelaskan bahwa anak-anak terkadang memiliki gagasan yang sangat banyak, akan tetapi anak belum mampu mengungkapkannya. Hal ini terjadi karena kemampuan bicaranya masih sangat terbatas dan jumlah kosa kata yang dimiliki anak masih terbatas.Keterbatasan jumlah kosa kata yang dimiliki anak dapat disebabkan oleh kurangnya stimulasi yang diberikan guru, orang tua maupun lingkungan jika tidak segera dikembangkan atau diberi stimulus maka akan dapat berdampak pada perkembangan aspekaspek yang lainnya.

Berdasarkan hasil observasi yang telah dilakukan di Kelompok A1 TK Madukismo, perkembangan bahasa yaitu kemampuan berbicara di Kelompok A1 Taman Kanak-Kanak Madukismo belum optimal dan masih perlu peningkatan. 9 dari 17 anak presentase $52.94 \%$ belum mampu berbicara dengan menggabungkan kata-kata menjadi kalimat yang bermakna; terbukti ketika anak mengungkapkan pengalaman atau bercerita hanya mengucap satu atau dua kata, bukan berupa kalimat. Anak masih belum dapat membedakan kata yang termasuk ke dalam kata benda, kata sifat dan kata kerja, Terbukti ketika berbicara di depan umum masih belum lancar dan kadang-kadang masih terbolakbalik dalam penyusunan kata.

Media pembelajaran yang kurang sesuai dengan kebutuhan anak, terbukti 
dengan penggunaan Lembar Kerja Anak dalam kegiatan berbahasa, yaitu anak menghubungkan gambar dengan tulisan di Lembar Kerja Anak sehingga kurang memberikan kesempatan kepada siswa untuk berbicara yang sesuai konteks kegiatan. Sebelumnya guru menjelaskan dengan menggunakan papan tulis yang kecil dan Lembar Kerja Anak dalam menyampaikan kegiatan pembelajaran.

Guru hanya menggunakan buku cerita kecil, majalah, lembar kerja anak ketika kegiatan bercerita sehingga kurang menarik minat dan perhatian anak. Kegiatan bercerita dilakukan dengan posisi duduk dan sesekali guru menegur siswa yang berbicara sendiri dengan harapan anak akan mendengarkan guru namun masih saja anak sering tidak terkondisikan atau berbicara sendiri dengan teman. Sehingga ketika guru bertanya, anak kesulitan dalam mengungkapkan kembali cerita yang disampaikan guru, terjadi karena kegiatan pembelajaran belum sepenuhnya berpusat pada anak.Hal ini membuat anak menjadi kurang terlibat aktif dalam pembelajaran.

Media pembelajaran atau alat permainan edukatif perlu dibuat semenarik mungkin untuk membantu mengoptimalkan kemampuan berpikir dan keterampilan berbicaradengan orang di sekitarnya, orangtua dan guru.Media yang diharapkan menarik ini, yaitu media panggung boneka.Media panggung boneka dipilihkarena pertunjukkan panggung boneka menyajikan hiburan sambil menyampaikan pesan-pesan pendidikan.Panggung boneka menjangkau semua umur sangat akrab dengan anakanak.(Rare, https://www.rare.org/id). Salah satu bentuk dari sekian banyak alat peraga yang dapat digunakan ialah boneka ( puppet). Boneka dapat digunakan dimanapun baik dengan latar dua dimensi atau tiga dimensi.

Berdasarkan latar belakang di atas, makaperlu diadakan perbaikan pembelajaran agar dapat mengoptimalkan perkembangan berbicara anak, kegiatan pembelajaran anak harus menyenangkan dan berpusat pada anak sehingga dapat meningkatkan keterampilan berbicara.Oleh karena itu media panggung boneka yang diterapkan diharapkan dapat meningkatkan keterampilan berbicara pada anak Kelompok A1 di TK Madukismo.

\section{METODE PENELITIAN Jenis Penelitian}

Jenis penelitian yang digunakan dalam penelitian ini adalah Penelitian Tindakan Kelas (classroom action research). Penelitian ini dilakukan karena adanya permasalahan dalam proses Kegiatan Belajar Mengajar di Kelompok A1 TK Madukismo, sehingga peneliti menganggap perlu adanya suatu penelitian guna mengatasi permasalahan tersebut. Selain itu penelitian ini juga dilakukan supaya guru mampu memperbaiki metode yang digunakan sehingga anak-anak akan mencapai perkembangan yang optimal. Penelitian Tindakan Kelas (PTK) adalah bentuk penelitian reflektif yang dilakukan oleh guru itu sendiri, yang hasilnya dapat dimanfaatkan sebagai alat untuk pengembangan sekolah, pengembangan keahlian mengajar dan sebagainya (Suroso, 2009: 29).Penelitian Tindakan Kelas (PTK) ini menggunakan model kolaborasi yang mengutamakan kerjasama antara guru dan peneliti untuk memperbaiki praktik-praktik pembelajaran sehingga menjadi lebih efektif.Penelitian ini dimaksudkan untuk meningkatkan keterampilan berbicara melalui penggunaan media panggung boneka.

\section{Waktu dan Tempat Penelitian}

Penelitian Tindakan Kelas ini dilaksanakan pada bulan September hingga November 2016 semester ganjil Tahun Ajaran 2016/2017.Penelitian siklus pertama dilaksanakan tiga kali dalam satu minggu.Dilaksanakan di TK Madukismo yang beralamatkan di Dusun Padokan, Kelurahan Tirtonirmolo, Kecamatan Kasihan, Kabupaten Bantul Yogyakarta. 


\section{Target/Subjek Penelitian}

Subyek dalam penelitian ini adalah semua siswa Kelompok A1 di TK Madukismo Bantul Yogyakarta.Jumlah siswa sebanyak 17 anak.8 anak laki-laki dan 9 anak perempuan.Peneliti memilih Kelompok A1 dikarenakan Kelompok A1 merupakan kelompok dengan usia yang akan memasuki sekolah dasar yaitu berada pada rentang usia 4-5 tahun dan keterampilan berbicara belum optimal

\section{Prosedur}

Penelitian ini berlangsung dalam dua siklus, Siklus I terdiri dari tiga kali pertemuan dan Siklus II terdiri dari tiga kali pertemuan.Penelitian ini menggunkan model penelitian dari Kemmis dan Mc Taggart (dalam Suharsimi Arikunto, 2006: 92).Model penelitian terdiri dari empat tahap yaitu perencanaan, tindakan, observasi, dan refleksi. Empat tahap tersebut dapat digambarkan pada Gambar 1 di bawah ini:

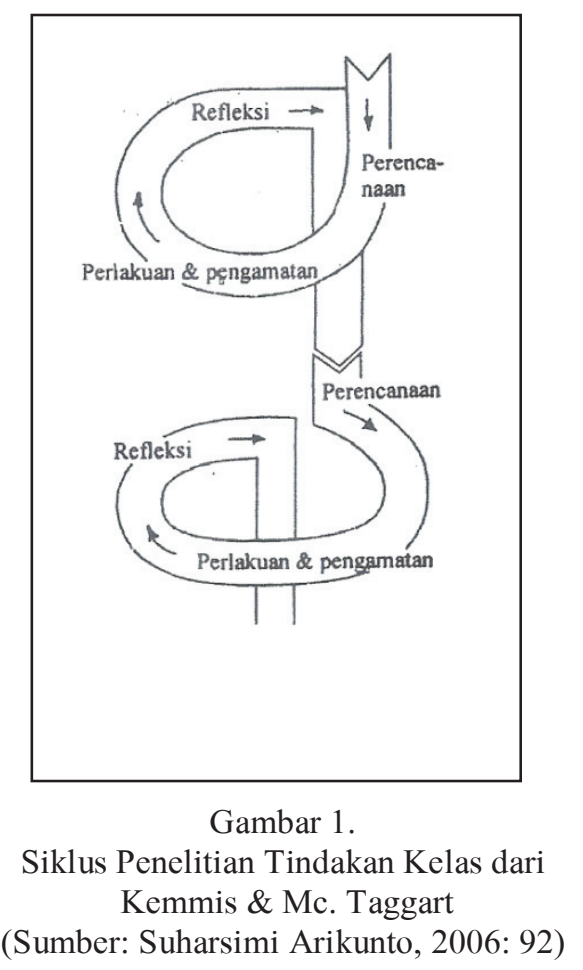

Alur pelaksanaan penelitian ini dilaksanakan dengan langkah-langkah sebagai berikut:

Kegiatan pra penelitian yaitu kegiatan yang dilakukan berupa mengamati proses saat kegiatan pembelajaran keterampilan berbicara pada anak di Kelompok A1 TK Madukismo guna melihat keterampilan berbicara anak.

Perencanaan yaitu menentukan tema dan sub tema binatang peliharaan yaitu burung,kura-kura. Binatang serangga yaitu laba-laba dan binatang buas serigala dan buaya;menyusun rencana pelaksanaan pembelajaran harian;mempersiapkan media yang akan digunakan yaitu panggung boneka, disertai dengan boneka tangan, boneka jari. Boneka tangan ada 13 macam dan boneka jari ada 10 macam;menyiapkan lembar observasi dan menyiapkan peralatan yang digunakan yaitu kamera untuk mendokumentasikan kegiatan anak.

Pelaksanaan penelitian yaitu merupakan penerapan langkah-langkah kegiatan berbicara melaluipenggunaan media panggung boneka yang disertai dengan penggunaan boneka jari dan tangan. Media tersebut digunakan diiringi dengan kegiatan bercerita

Penggunaan panggung boneka dengan boneka jari dan tangan, langkah-langkah sebagai berikut: (1) guru bercerita, (2) guru melakukan Tanya jawab tentang cerita yang dibawakan dan (3) anak mengulang cerita yang dibawakan guru. (4) Guru memberi motivasi kepada anak untuk ikut aktif berpartisipasi. Pada pelaksanaan di siklus II terdapat perbedaan pelaksanaan langkah-langkah bercerita yaitu 1) guru bercerita, (2) guru melakukan Tanya jawab tentang cerita yang dibawakan dan (3) anak mengulang cerita yang dibawakan guru dalam kelompok. Setiap kelompok terdapat 10 hingga 13 boneka tangan dan panggung boneka. Anak bercerita dengan panggung boneka dalam kelompok (4) Guru memberi motivasi kepada anak untuk ikut aktif berpartisipasi.

Observasi dilakukan pada saat anak melakukan kegiatan berbicara dengan menggunakan lembar observasi yang 
dalam pengisiannya diberi tanda checklist dan mendokumentasikan kegiatan anak.

Refleksi dilakukan dengan cara berdiskusi dengan pendidik mengenai kendala yang dihadapi dan merencanakan perbaikan pada siklus selanjutnya.

\section{Data, Instrumen, dan Teknik Pengumpulan Data}

Metode pengumpulan data yang dipakai dalam penelitian ini menggunakan observasi dan dokumentasi.Melalui metode observasi peneliti mengamati langsung kegiatan berbicara melaluipenggunaan panggung boneka. Hasil kegiatan dicatat dalam lembar observasi dengan memberi tanda checklist. Pada penelitian ini, dokumentasi dilakukan dengan cara mengambil foto anak dan arsip-arsip lain pada saat kegiatan pembelajaran meningkatkan keterampilan berbicara melalui penggunaan panggung boneka Penelitian ini menggunakan instrumen yang terdapat pada

Tabel 1 berikut ini:

Tabel 1. Kisi-kisi Lembar Observasi

\begin{tabular}{|c|c|c|}
\hline Variabel & Indikator & $\begin{array}{c}\text { Aspek yang } \\
\text { diamati }\end{array}$ \\
\hline \multirow[t]{2}{*}{$\begin{array}{c}\text { Keterampilan } \\
\text { berbicara }\end{array}$} & $\begin{array}{l}\text { Aktif } \\
\text { berpartisipasi } \\
\text { mengungkapkan } \\
\text { ide / gagasan }\end{array}$ & $\begin{array}{l}\text { - Keaktifan } \\
\text { dan } \\
\text { kelancaran } \\
\text { berbicara }\end{array}$ \\
\hline & $\begin{array}{l}\text { Menjawab } \\
\text { pertanyaan apa, } \\
\text { siapa, mengapa, } \\
\text { dan dimana }\end{array}$ & - Ketepatan \\
\hline
\end{tabular}

\section{Teknik Analisis Data}

Analisis data dalam penelitian ini menggunakan data deskriptif kualitatif dan kuantitatif. Persentase keterampilan berbicara, data dianalisis menggunakan analisa deskriptif kuantitatif. Rumus yang digunakan dalam penelitian ini Muhammad Ali (1995: 184)yaitu sebagai berikut

Keterangan:

$$
\text { Persentase }=\frac{\mathrm{n}}{\mathrm{N}} \times 100 \%
$$

$\mathrm{p}=$ persentase yang hendak dicari

$\mathrm{n}=$ Jumlah skor yang diperoleh

$\mathrm{N}=$ Jumlah seluruh skor ideal
Langkah-langkah analisis dalam penelitian ini yaitu:

Hasil observasi diberi skor (3, 2, atau 1) pada setiap masing-masing indikator keterampilan berbicara.

Masing-masing indikator dihitung rataratapada setiap pertemuan

Persentase keberhasilan dihitung dengan cara skor pada setiap indikator dijumlah lalu dibagi dengan skor maksimal.

Hasil persentase setiap indikator tersebut akan menghasilkan rata-rata ketercapaian anak pada setiap pertemuannya.

Analisis data diambil berdasarkan hasil persentase rata-rata keterampilan berbicara pada setiap pertemuan kemudian dipaparkan selisihnya.

Hasil persentase setiap siklus nya diperjelas dalam bentuk tabel dan grafik.

Anas Sudijono (2010: 43)
menyatakan bahwa data diinterpretasikan ke dalam 4 tingkatan yang terdapat dalam Tabel 2 berikut ini:

Tabel 2. Kriteria Keberhasilan

\begin{tabular}{lc}
\hline \multicolumn{1}{c}{ Kriteria } & Skor Rata-rata \\
\hline Baik & $80 \%-100 \%$ \\
\hline Cukup & $60 \%-79 \%$ \\
\hline Kurang baik & $30 \%-59 \%$ \\
\hline Tidak baik & $0 \%-29 \%$ \\
\hline
\end{tabular}

\section{HASIL PENELITIAN PEMBAHASAN Hasil Penelitian}

Data Pra Tindakan

Peneliti melakukan pengamatan terhadap kondisi awal kemampuan berbicara anak sebelum dilaksanakannya tindakan. Kegiatan pengamatan untuk mengetahui kondisi awal siswa merupakan kegiatan Pra Tindakan dan menggunakan lembar observasi yang sudah tersedia.

Pra Tindakan bertujuan untuk mengetahui kemampuan anak dalam hal menjawab pertanyaan (apa, siapa, mengapa, dimana) selain itu guna mengetahui kemampuan anak dalam ikut aktif berpartisipasi mengungkapkan ide 
atau gagasan diperoleh data dalam Tabel 3 berikut:

Tabel 3. Rekapitulasi Kondisi Awal Keterampilan Berbicara

\begin{tabular}{lc}
\hline \multicolumn{1}{c}{ Indikator } & Presentase \\
\hline $\begin{array}{l}\text { Aktif berpartisipasi } \\
\text { mengungkapkam } \\
\text { ide/gagasan }\end{array}$ & $51.2 \%$ \\
\hline $\begin{array}{l}\text { Menjawab pertanyaan (apa, } \\
\text { siapa, mengapa dimana) }\end{array}$ & $54.4 \%$ \\
\end{tabular}

\begin{tabular}{cc}
\hline Rata - rata & $52.8 \%$ \\
\hline
\end{tabular}

$\begin{array}{rrr}\text { Pelaksanaan } & \text { pra } & \text { tindakan } \\ \text { dilaksanakan } & \text { satu } & \text { kali }\end{array}$
pertemuandilaksanakan selama 45 menit. Pelaksanaan pratindakan dalam hal ini guru bertindak sebagai pengajar dan peneliti bertindak sebagai pengamat.

Berdasarkan hasil observasi, dapat dilihat bahwa hasil Pratindakan menggunakan lembar observasi (checklist) pada indikator aktif berpartisipasi mengungkapkam ide/gagasan adalah $51.2 \%$, indikator mampu menjawab pertanyaan adalah sebesar 54.4\%. Ratarata keterampilan berbicara pada tahap Pratindakan hanya sebesar $52.8 \%$.

Pelaksanaan tindakan Siklus I sebanyak tiga kali pertemuan. Setiap pertemuan dilaksanakan selama 45 menit. Pelaksanaan tindakan siklus pertama dalam hal ini guru bertindak sebagai pengajar dan peneliti bertindak sebagai pengamat.

Dalam pelaksanaan penggunaan media panggung boneka diikutsertakan dengan kegiatan bercerita.Kegiatan bercerita dengan media panggung boneka dilaksanakan pada kegiatan awal dengan anak duduk secara klasikal pada tempat duduk masing masing. Langkah-langkah pelaksanaan kegiatan berbicara menggunakan panggung boneka adalah sebagai berikut:

guru bercerita menggunakan media panggung boneka

guru melakukan Tanya jawab tentang cerita yang dibawakan

anak mengulang cerita yang dibawakan guru. Anak maju satu persatu dengan menggunakan boneka jari
Guru memberi motivasi kepada anak untuk ikut aktif berpartisipasi.

\section{Pelaksanaan Siklus I}

Pelaksanaan Siklus I dilaksanakan dalam tiga kali pertemuan, setiap pertemuannya selama 45 menit.Pertemuan Pertama dengan tema binatang dan sub tema binatang peliharaan. Pertemuan kedua dengan tema binatang dan sub tema binatang peliharaan (burung).Pertemuan Ketiga dengan tema binatang dan sub tema binatang peliharaan (kura-kura).

Pada siklus pertama rata-rata keterampilan berbicara anak sebesar $65.6 \%$.Dengan demikian rata-rata keterampilan berbicara anak dalam pelaksanaan tindakan Siklus I telah terjadi peningkatan sebesar $12.8 \%$.Hal ini dibuktikan rata-rata keterampilan berbicara anak dalam Pratindakan hanya 52.8\% meningkat pada Siklus I menjadi $65.6 \%$.

\section{Pelaksanaan Siklus II}

Pelaksanaan Siklus II dilaksanakan dalam tiga kali pertemuan.Pertemuan Pertama dengan tema binatang dan sub tema serangga (laba - laba). Pertemuan Kedua dengan tema binatang dan sub tema binatang buas (buaya). Pertemuan Ketiga dengan tema binatang dan sub tema binatang buas (serigala)

Pelaksanaan siklus II diperoleh data sesuai dengan table di baawah ini. tabel 4 yang menyajikan data pencapaian keterampilan berbicara Siklus II:

Table 4.Pencapaian Keterampilan Berbicara Siklus II

\begin{tabular}{cc}
\hline Indikator & Presentase \\
\hline Keaktifan berbicara & $86.6 \%$ \\
\hline Menjawab pertanyaan & $89.6 \%$ \\
\hline Rata - rata & $88.1 \%$ \\
\hline
\end{tabular}

Rata-rata keterampilan berbicara anak sebesar $88,1 \%$. Dengan demikian ratarata keterampilan berbicara anak dalam pelaksanaan tindakan Siklus II telah terjadi peningkatan sebesar 22.5\%. Hal ini dibuktikan rata-rata keterampilan berbicara anak dalam Siklus I hanya $65.6 \%$ meningkat pada Siklus II menjadi 88,1\%. 
Rekapitulasi hasil data keterampilan berbicara dari Pra Tindakan, Siklus I, dan Siklus II:

Tabel 5. Rekapitulasi Keterampilan Berbicara

\begin{tabular}{|l|c|c|c|}
\hline \multicolumn{1}{|c|}{ Indikator } & Pratindakan & Siklus 1 & Siklus 2 \\
\hline $\begin{array}{l}\text { Keaktifan } \\
\text { berbicara }\end{array}$ & 51.2 & 65.1 & 86.6 \\
\hline $\begin{array}{l}\text { Menjawab } \\
\text { pertanyaan }\end{array}$ & 54.4 & 66.1 & 89.6 \\
\hline Rata - rata & $\mathbf{5 4 . 8 2}$ & $\mathbf{5 4 . 8 2}$ & $\mathbf{8 8 . 1}$ \\
\hline
\end{tabular}

Pada Tabel 5 rekapitulasi keterampilan berbicara di atas dapat dilihat bahwa indikator keaktifan berbicara pada Pra Tindakan yaitu 51,2\%, indikator menjawab pertanyaan yaitu $54,4 \%$, dengan demikian dapat dilihat bahwa pada Pra Tindakan diperoleh rata-rata 54,82\%. Pada Siklus I, indikator keaktifan berbicara mencapai $65,1 \%$, indikator menjawab pertanyaan mencapai $66,1 \%$, dengan demikian dapat dilihat bahwa pada Siklus I diperoleh rata-rata $65,6 \%$. Pada Siklus II, indikator keaktifan berbicara mencapai $86,6 \%$, indikator menjawab pertanyaan mencapai $89,6 \%$, dengan demikian dapat dilihat bahwa pada pada Siklus II diperoleh rata-rata $88,1 \%$.

Peningkatan hasil pencapaian keterampilan berbicara pada Pra Tindakan, Siklus I, dan Siklus II dapat disajikan dalam Gambar 2 di bawah ini:

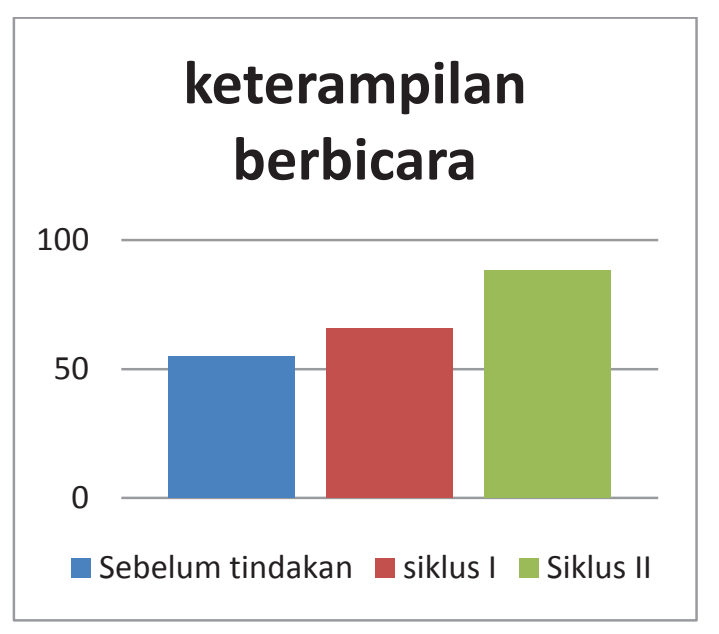

Gambar 2.

Grafik Peningkatan Keterampilan Berbicara
Data pada tabel 5 menunjukkan peningkatan keterampilan berbicara Pra Tindakan, Siklus I, dan Siklus II yang berada pada kriteria baik. Pada Pra tindakan rata-rata pencapaian keterampilan berbicara hanya $54,82 \%$ dan pada Siklus I keterampilan berbicara meningkat menjadi $65,6 \%$. Pada Siklus II, peningkatan keterampilan berbicara menjadi $88,1 \%$.

\section{PEMBAHASAN}

Penelitian yang dilakukan merupakan penelitian tindakan kelas yang dilakukan dalam dua siklus.Setiap siklus terdiri dari perencanaan, tindakan, observasi, dan refleksi. Hasil yang diperoleh dalam penelitian merupakan hasil dari pengamatan tentang keterampilan berbicara yang mencakup dua indikator yaitu, aktif berbicara dan mampu membentuk kalimat dengan runtut, menjawab pertanyaan dari guru (apa, siapa, mengapa, dimana).

Penggunaan media panggung boneka yang diikutsertkan kegiatan bercerita dipilih karena pada dasarnya anak senang mendengarkan cerita.Hal ini sesuai pendapat Sanders (dalam Tadzkirotun Musfiroh, 2005: 26) ada beberapa alasan penting mengapa anak perlu mendengarkan cerita.Salah satunya karena mendengarkan cerita merupakan sesuatu yang menyenangkan bagi anak. Anak dapat lebih bergairah untuk belajar karena pada dasarnya anak senang mendengarkan cerita.Meningkatkan keterampilan berbicara dengan metode ercerita saja ternyata tidak cukup.Diperlukan suatu media yang dapat menarik perhatian anak pada saat bercerita.

Media yang digunakan tentunya disesuaikan dengan karakteristik anak.Maka peneliti menggunakan media boneka karena sesuai dengan karakteristik anak.Hal ini sesuai dengan pendapat Piaget (dalam Slamet Suyanto, 2005: 53- 67). Anak usia 4-5 tahun berada pada masa Praoperasional. Pada masa ini anak mampu mengadakan representatif dunia pada tingkatan yang konkret.Boneka menjadi 
alat peraga yang dianggap mendekati naturalitas bercerita boneka ada bermacammacam di antaranya boneka tangan. Jika dibandingkan dengan jenis boneka yang lain, boneka tangan lebih mudah digunakan dan lebih leluasa bergerak sehingga anak bisa berinteraksi dengan boneka. Sesuai dengan pendapat Nurbiana Dhieni, Lara Fridani, Gusti Yarmi, \& Nany Kusniaty (2005: 38) yang menyebutkan bahwa dalam kegiatan pembelajaran akan lebih baik apabila guru memberikan reinforcement (penguat), reward (pujian, hadiah), stimulasi, dan odel atau contoh yang baik dari orang dewasa agar keterampilan berbicaranya dapat berkembang secara maksimal.

Dari hasil refleksi Siklus II diketahui bahwa anak antusias dalam mendengarkan cerita.Suasana lebih kondusif karena anak yang banyak bicara tidak membuat ramai lagi. Anak juga antusias saat diminta untuk maju ke depan untuk menceritakan kembali isi cerita yang baru saja dibawakan. Hal ini terbukti saat guru meminta anak untuk menceritakan kembali, guru tidak perlu menunjuk siapa yang maju tetapi anak sudah berlombalomba untuk maju.Selain itu anak lebih percaya diri dan termotivasi untuk menceritakan kembali isi cerita dengan baik karena adanya penghargaan.

Dari hasil yang diperoleh pada Siklus II selama tiga kali pertemuan menunjukkan bahwa kemampuan berbicara meningkat menjadi $88,1 \%$. Anak yang mengalami peningkatan dalam kemampuan berbicara adalah anak yang pada saat aktif berbicara baik itu menceritakan kembali isi cerita sudah mampu berbicara dengan kalimat jelas dan runtut maupun hanya aktif menanggapi di tempat duduk,mampu menjawab pertanyaan dari guru (apa, siapa, dimana, mengapa).

Apabila mengacu pada indikator keberhasilan, maka tindakan dapat dikatakan berhasil. Keberhasilan tindakan juga tidak terlepas dari pengaruh menggunaan panggung boneka. Dengan panggung boneka, kualitas cerita dan performansi cerita menjadi meningkat.Hal ini sejalan dengan pendapat Tadzkirotun Musfiroh (2005: 147) menyatakan bahwa manfaat dari panggung boneka adalah untuk meningkatkan kualitas dan performansi cerita.Panggung boneka yang digunakan adalah panggung boneka yang terbuat dari kayu permanen.Ukuran panggung boneka kecil agar anak-anak juga bisamenggunakannya. Dari hasil penelitian, $88,1 \%$ keterampilan berbicara anak masuk kriteria sangat baik.

Berdasarkan data yang diperoleh dapat disimpulkan bahwa menggunakan media panggung boneka dapat meningkatkan keterampilan berbicara anak Kelompok A1 TK Madukismo Kasihan, Bantul.

\section{SIMPULAN DAN SARAN}

\section{Simpulan}

Berdasarkan hasil penelitian dan pembahasan yang telah dilakukan dapat disimpulkan bahwa penggunaan panggung boneka dapat meningkatan keterampilan berbicara pada anak kelompok A1 di TK Madukismo, Kasihan, Bantul. Hal ini dapat dilihat dari kemampuan awal keterampilan berbicara yaitu $52.8 \%$ termasuk ke dalam krtiteria kurang baik, pada akhir siklus I meningkat menjadi $65.6 \%$ termasuk kedalam kriteria cukup, pada akhir siklus II meningkat menjadi $88.1 \%$ termasuk dalam kriteria baik.

Peningkatan keterampilan berbicara anak meningkat melalui panggung boneka dengan langkah-langkah berikut yaitu (1) guru bercerita, (2) guru melakukan Tanya jawab tentang cerita yang dibawakan dan (3) anak mengulang cerita yang dibawakan guru. (4) Guru memberi motivasi kepada anak untuk ikut aktif berpartisipasi. Peningkatan keterampilan berbicara anak jika dilihat dari hasilpenelitian anak sudah dapat aktif berpasrtisipasi berbicara dan dapat menjawab semua pertanyaan guru. Keterampilan berbicara anak kelempok A1 melaluimedia panggung boneka untuk meningkatkan proses kegiatan pembelajaran dengan tidak hanya berpusat 
pada satu guru. Selain itu pemberian kesempatan berbicara untuk setiap anak menjadikanan anak lebih terampil berbicara.

\section{Saran}

Saran yang dapat diberikan oleh peneliti berdasarkan hasil penelitian yang telah dilakukan adalah sebagai berikut.

a. Dalam kegiatan berbicara sebaiknya menggunakan media panggung boneka dengan tata panggung serta warna yang menarik dan setiap anak diberi satu boneka sehingga anak lebih aktif berpartisipasi dalam berbicara.

b. Guru dapat melakukan pembaharuan dalam meningkatkan keterampilan berbicara melalui penggunaan media panggung boneka yang wayangnya dapat diubah- ubah atau diganti dengan benda konkrit (nyata).

\section{DAFTAR PUSTAKA}

Anas Sudijono.(2010). Pengantar Statistik Pendidikan. Jakarta: Rineka Cipta.

Harun Rasyid,Mansyur, \& Suratno (2009). Asesmen Perkembangan Anak Usia Dini. Yogyakarta: Multi Pressindo.
Henry Guntur Tarigan .(2008). Berbicara Sebagai Suatu Keterampilan Berbahasa.Bandung: Angkasa

Nurbiana Dhieni, Lara Fridani, Gusti Yarmi, \& Nany Kusniaty. (2005). Metode Pengembang Bahasa. Jakarta: Pusat Penerbitan Universitas Terbuka.

Rare.(2016). Memulai Media Panggung Boneka. Diakses tanggal 22 juli 2016 dari https://www.rare.org/id/node/316 WEEW3bkXXIU

Suharsimi Arikunto. (2006). Prosedur Penelitian. Jakarta: PT. Rineka Cipta.

Suroso.(2009). Penelitian tindakan kelas.Yogyakarta: Pararaton

Tadkiroatun Musfiroh. (2005). Bercerita untuk anak usia dini. Jakarta: Departemen Pendidikan Nasional 